\title{
A PROSPECTIVE STUDY OF FUNCTIONAL OUTCOME OF DISPLACED MIDSHAFT CLAVICLE FRACTURES TREATED WITH INTRAMEDULLARY TITANIUM ELASTIC NAIL SYSTEM
}

\author{
Kolundan Kalyanasundaram¹, Selvam Sasi Kumar², Anbu Srinivasan³, Balusamy Ramesh ${ }^{4}$
}

${ }^{1}$ Associate Professor, Department of Orthopaedics, KAP Viswanatham Government Medical College/MGMGH, Tiruchirapalli ${ }^{2}$ Assistant Professor, Department of Orthopaedics, KAP Viswanatham Government Medical College/MGMGH, Tiruchirapalli ${ }_{3}^{3}$ Associate Professor, Department of Orthopaedics, KAP Viswanatham Government Medical College/MGMGH, Tiruchirapalli ${ }_{4}^{4}$ Assistant Professor, Department of Orthopaedics, KAP Viswanatham Government Medical College/MGMGH, Tiruchirapalli

ABSTRACT

\section{BACKGROUND}

Clavicle fractures are common injuries in young and active individuals, especially those who participate in sports where high-speed falls (e.g., bicycling, motorcycles) or violent collisions (e.g. Football, hockey) are frequent. Whereas in children and elderly, they are related to falls and they account for approximately $2.6 \%$ of all fractures. The most common site of fracture in the clavicle occurs at the middle third which accounts for almost $80 \%$ of all clavicle fractures. Displaced midshaft clavicle fractures can cause significant, persistent disability, even if they heal uneventfully. The clavicle which is similar to other long bones is usually best treated with intramedullary methods. So elastic stable intramedullary nailing (ESIN) is recommended for all simple displaced midshaft clavicle fractures in order to minimise the rate of delayed union, non-union, symptomatic malunion and other complications.

\section{MATERIALS AND METHODS}

This is a prospective case series to study the functional outcome of 40 cases of displaced midshaft clavicle fractures, satisfying the inclusion criteria, treated by intramedullary titanium elastic nail system done at the Department of Orthopaedics, Government Kilpauk Medical College Hospital, Chennai from September 2013 to July 2015. All cases were treated with TENS under the guidance of the image intensifier as per standard methods.

\section{RESULTS}

In the group, 24 patients had AO class B1 and 16 had AO class B2 fractures. All the patients achieved clinical and radiological union at a mean of 8.8 weeks (Range 6-12 weeks). Eleven of the 24 patients had closed nailing while 16 patients (40\%) required open reduction of their fracture. The average size of the titanium flexible nail used was $2.5 \mathrm{~mm}$ (range $2-3 \mathrm{~mm}$ ). The average constant score was 89.8 (range 78 - 95).

\section{CONCLUSION}

From this study, we recommend the use of minimally invasive antegrade titanium elastic nail for fixation of displaced midshaft clavicle fractures in view of faster fracture union, quicker rehabilitation, lesser morbidity, easier implant removal and fewer complications.

\section{KEYWORDS}

Clavicle Fracture, ESIN, AO Class B1 and B2.

HOW TO CITE THIS ARTICLE: Kalyanasundaram K, Kumar SS, Srinivasan A, et al. A prospective study of functional outcome of displaced midshaft clavicle fractures treated with intramedullary titanium elastic nail system. Dent. Sci. 2018;7(01):86-93, DOI: 10.14260/jemds/2018/20

\section{BACKGROUND}

Clavicle fractures accounting for approximately $2.6 \%$ of all fractures $^{1}$ are usually common in young and active individuals and usually due to high velocity injuries whereas simple fall is the common aetiology of clavicle fracture in elderly and young children. By far the commonest site of clavicle fracture is the middle third region accounting for almost $80 \%$ of all clavicle fractures. Older studies usually advised conservative line of management in fractured clavicle, even when displaced significantly, deeming it to be benign in nature.2,3

'Financial or Other Competing Interest': None.

Submission 01-11-2017, Peer Review 12-12-2017,

Acceptance 18-12-2017, Published 01-01-2018.

Corresponding Author:

Selvam Sasi Kumar

AA-28, Ukkarakali Amman Kovil Street,

Anna Nagar, Tennur, Trichy- 620017.

E-mail: dr.sasiselvam@gmail.com

DOI: $10.14260 /$ jemds $/ 2018 / 20$

\section{(c) ()$_{\mathrm{BY}} \bigodot_{\mathrm{NC}}$}

Non-union rates according to Neer were $0.1 \%$ with conservative management which was corroborated by Rowe in 1968 whose studies showed non-union occurring at the rate of $0.8 \%$ in conservatively managed clavicle fractures. ${ }^{4}$ But since that no authors have achieved quite similar good results with conservative line of management in clavicle fractures. .5

Zlowodzki et al did meta-analysis of the literature from 1975-2005 and found that the non-union rate for conservatively managed midshaft clavicle fractures was $15.1 \%$ higher than described previously. ${ }^{7}$

Further study by Hill et al reported non-union rate of $15 \%$ in patients treated by conservative methods who presented with shortening greater than $2 \mathrm{~cm}$ after injury. Hill et al also reported that $31 \%$ of patients were not satisfied with their final result obtained by conservative means. ${ }^{8}$

All these evidences clearly suggest that mid shaft clavicle fractures indeed produce significant disability even though their healing were uneventful. Clavicle is similar to other long bones and can be treated with intramedullary fixation. Elastic Stable Intramedullary Nailing (ESIN), thus is a good option 
for displaced midshaft clavicle fracture which effectively minimises delayed union, reduces incidence of non-union, reduces symptomatic malunion and other complications.

\section{MATERIALS AND METHODS}

This is a prospective case series to study the functional outcome of 40 cases of displaced midshaft clavicle fractures treated by intramedullary titanium elastic nail system done at the Department of Orthopaedics, Government Kilpauk Medical College Hospital, Chennai from September 2013 to July 2015. The study was formally approved by hospital ethics committee.

\section{Inclusion Criteria}

- All skeletally mature patients.

- All the displaced diaphyseal non-comminuted/simple comminuted clavicle fractures ( $>2 \mathrm{~cm}$ displacement)- $\mathrm{AO}$ $15 \mathrm{~B} 1$ and B2 fractures.

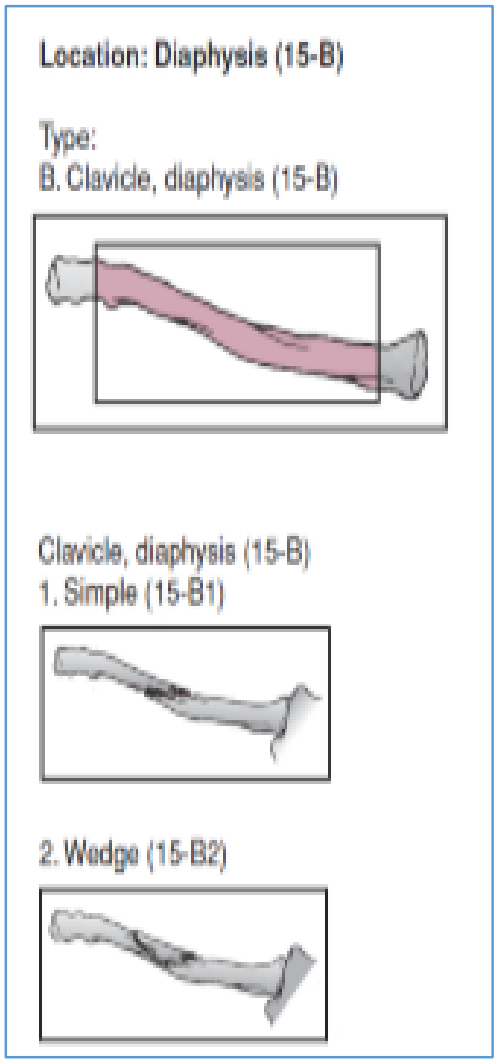

Figure 1. A0 Classification

- Fractures with shortening of over $20 \mathrm{~mm}$

- Fractures within one week

\section{Exclusion Criteria}

- Fractures with marked comminution

- Brachial plexus injuries

- Fractures older than 1 week

- Paediatric fractures

- Pathological fractures

- Open fractures

- Congenital anomaly or bone disease

- Any medical contraindication for surgery

\section{Classification}

We used AO/OTA classification in our study.

\section{Outcome Assessment}

Functional outcome was assessed by the Constant score. Radiographic union was defined as evidence of bridging callus or obliteration of fracture lines.

Clinical union was considered as absence of tenderness at the fracture site. Time to achieve union was recorded. After union, shortening of clavicular length was measured clinically as the linear difference of clavicle lengths from Sternal end to Acromial end between operated and normal side.

Secondary outcome measures include perioperative data like operative time, amount of blood loss and size of the surgical wound; complications such as neurovascular injury, wound infection, nonunion, malunion, implant migration, implant failure, soft tissue irritation, re-fracture after implant removal and cosmetic outcome with regards to visible deformity, scars and hardware prominence under the skin. Implant removal was done routinely in our study.

\section{Statistical Analysis}

The collected data was analysed with IBM SPSS version 22 for independent sample t-test. The results are obtained in the form of range, mean and standard deviation. The probability value ' $\mathrm{p}$ ' of less than 0.05 was considered statistically significant.

\section{RESULTS}

Case 1.

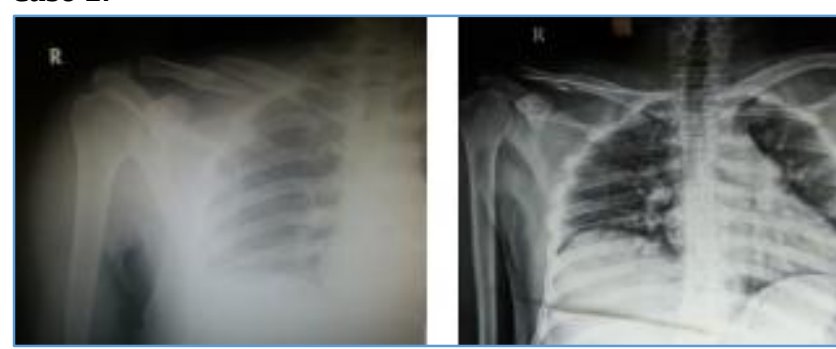

Figure 9. Preoperative X-ray

Figure 10. Immediate Post-op
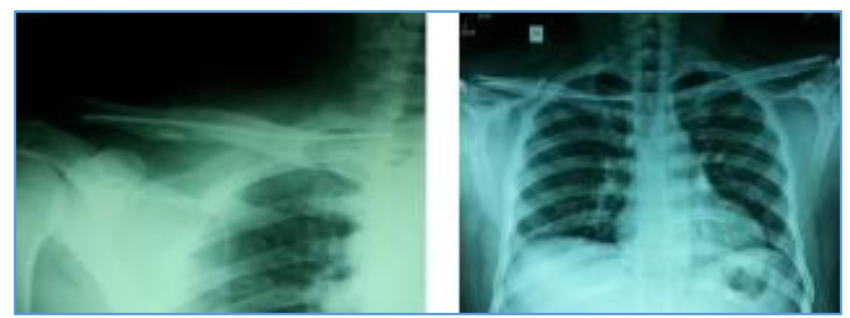

Figure 11. Six Weeks Post-op

Figure 12. Six Months Post-op

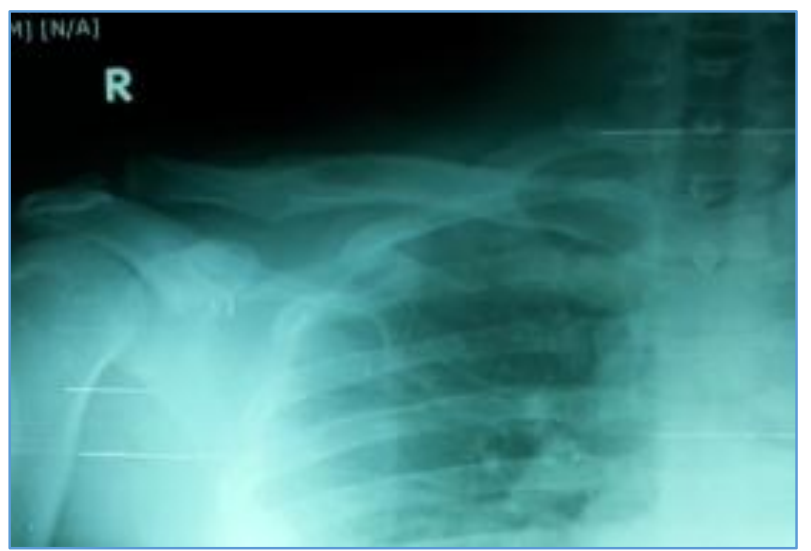

Figure 13. After Removal 


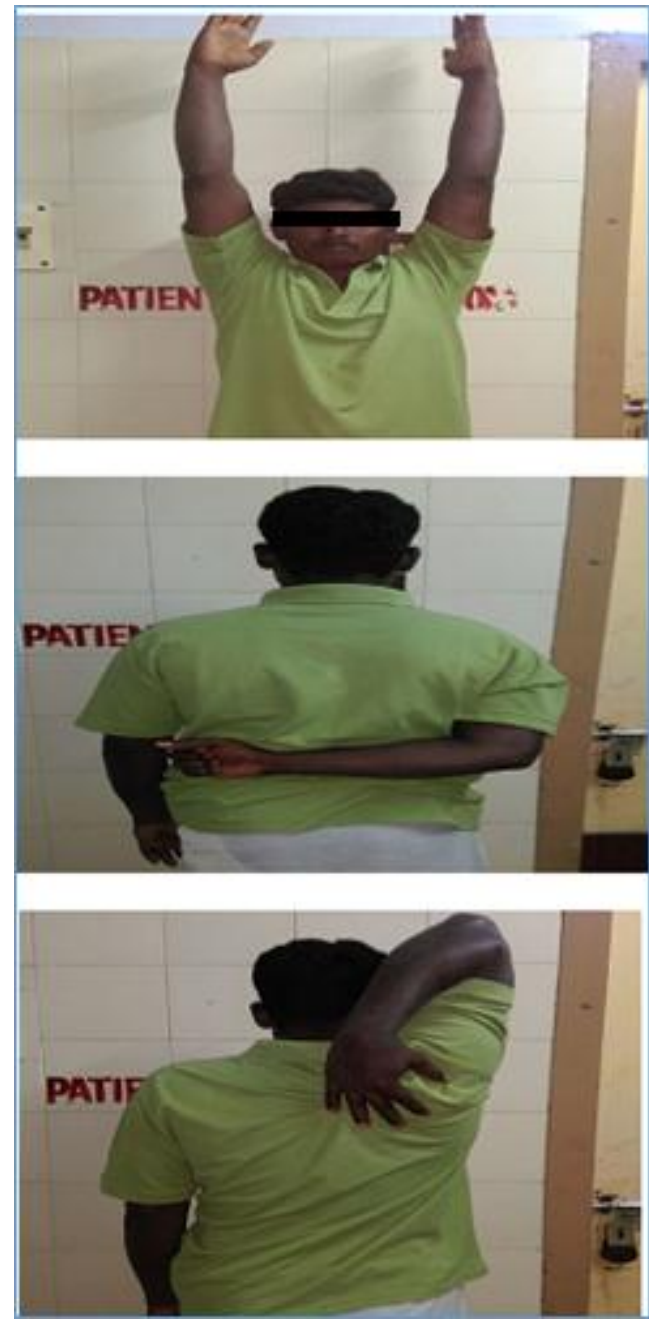

Figure 14. Postoperative Range of Movements

Case 2.

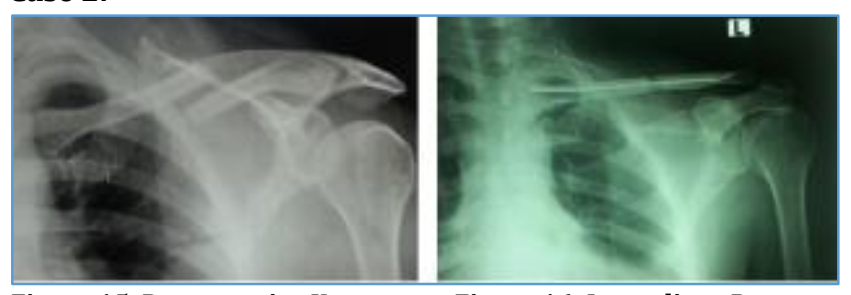

Figure 15. Preoperative X-ray Figure 16. Immediate-Post-op

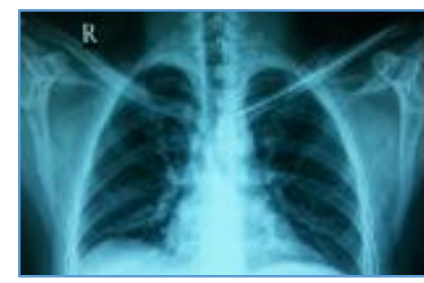

Figure 17. One Month Post-op

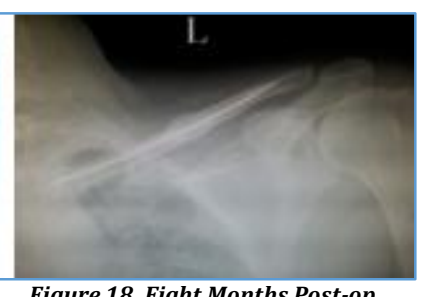

Figure 18. Eight Months Post-op

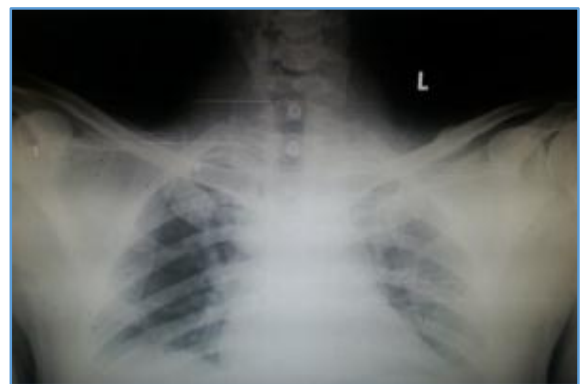

Figure 19. After Removal
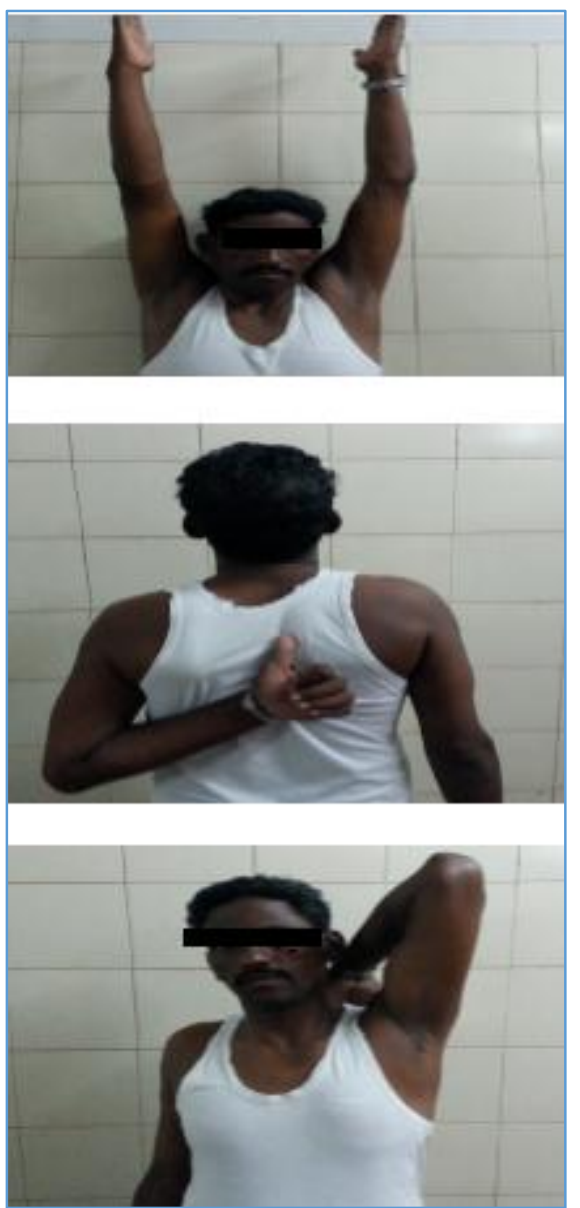

Figure 20. Postoperative Range of Movements

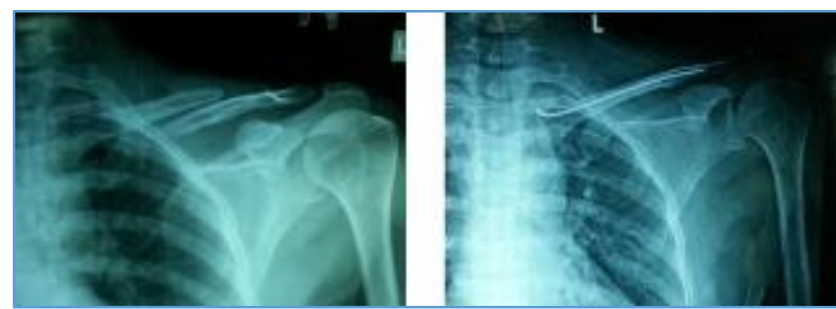

Figure 21. Pre-operative X-ray

Figure 22. Immediate Post-op

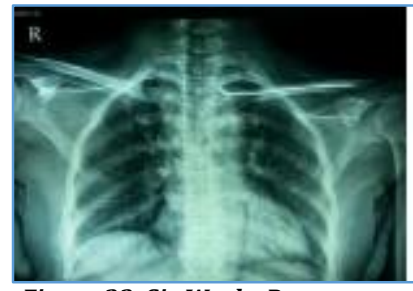

Figure 23. Six Weeks Post-op

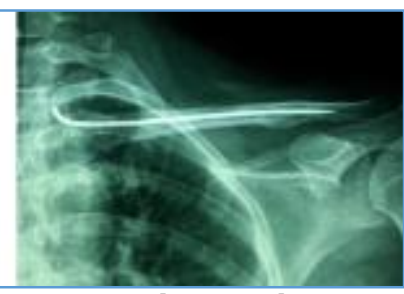

Figure 24. Three Months Post-op

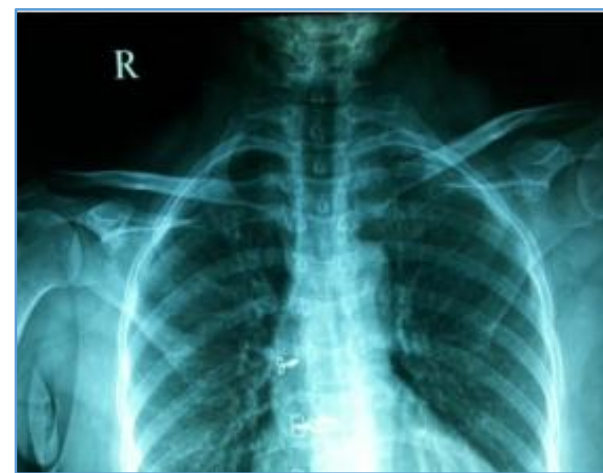

Figure 25. After Removal 


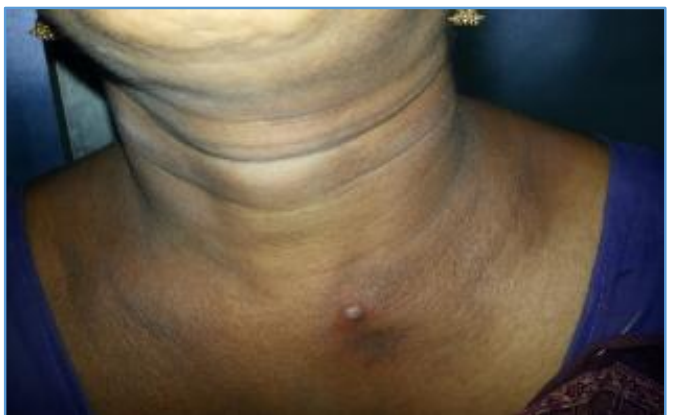

Figure 26. Complication of TENS Nail Showing Medial Hardware Prominence and Local Skin Perforation

This 45-year-old female had medial implant prominence and local infection which was treated with antibiotics. But the implant has to be removed at about 3 months post-op when she presented with skin perforation. By the time the fracture had united both clinically and radiologically resulting in no complications after implant removal.

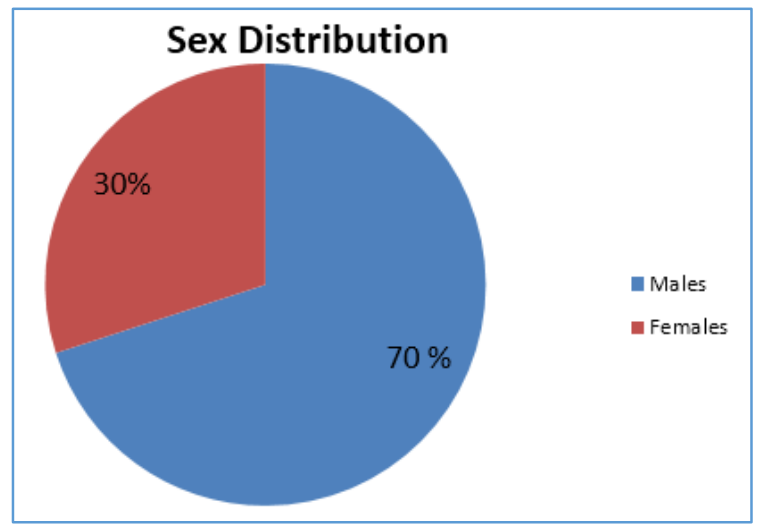

Figure 27. Sex Distribution

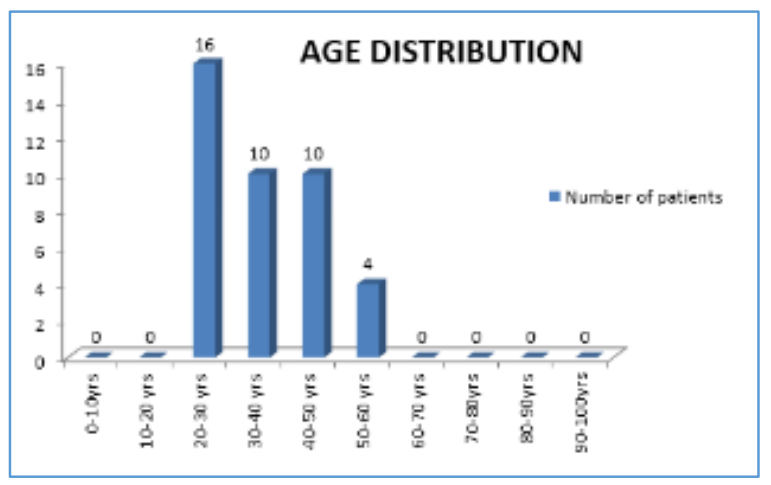

Figure 28. Age Distribution

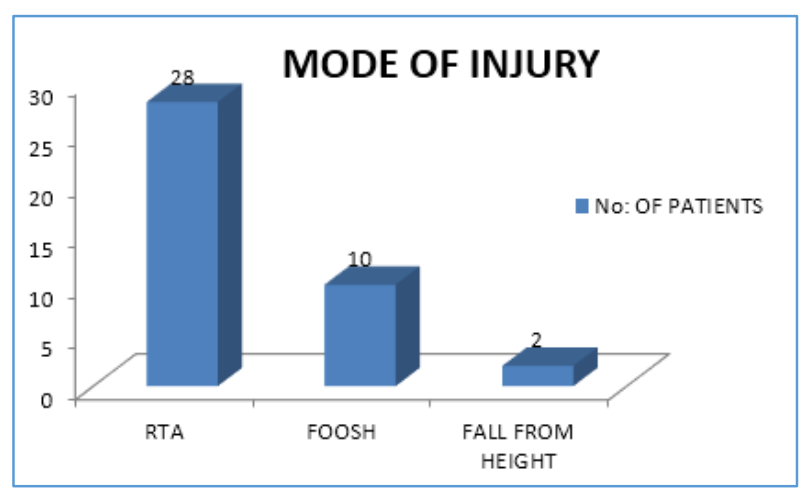

Figure 29. Mode of Injury

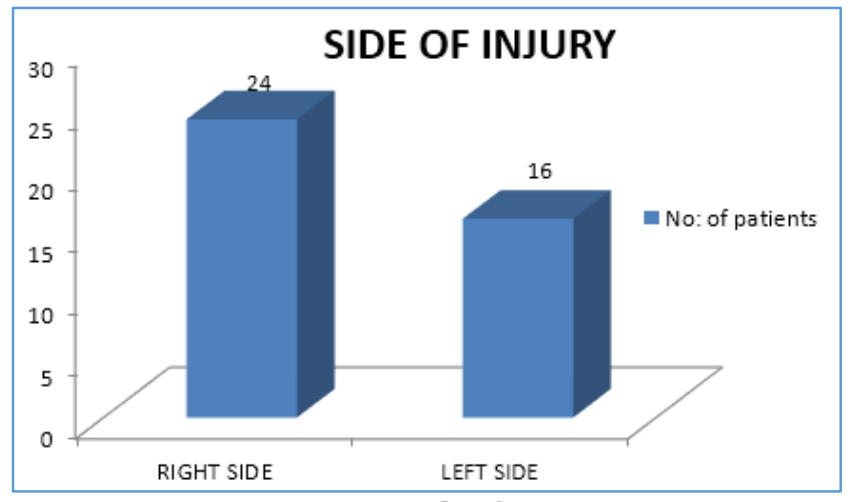

Figure 30. Side of Injury

\section{Associated Injuries}

In the study group, we had only two patients with associated injuries, which included- One case of ipsilateral spine of scapula fracture and another case with ipsilateral fracture both bone leg, both of them were addressed simultaneously.

\section{Fracture Classification}

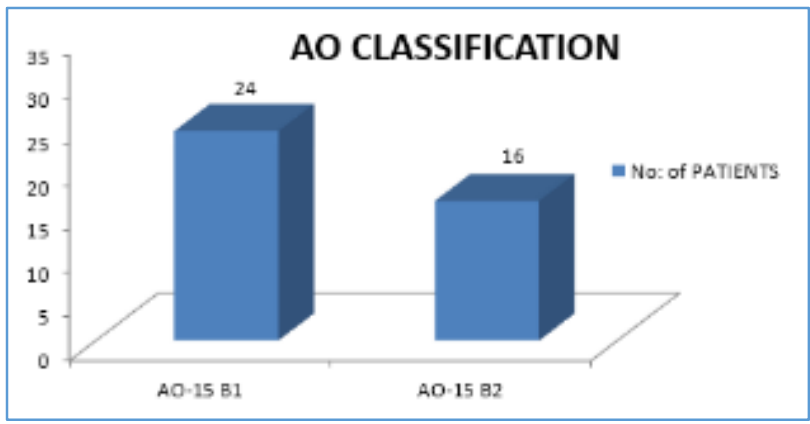

Figure 31. Classification

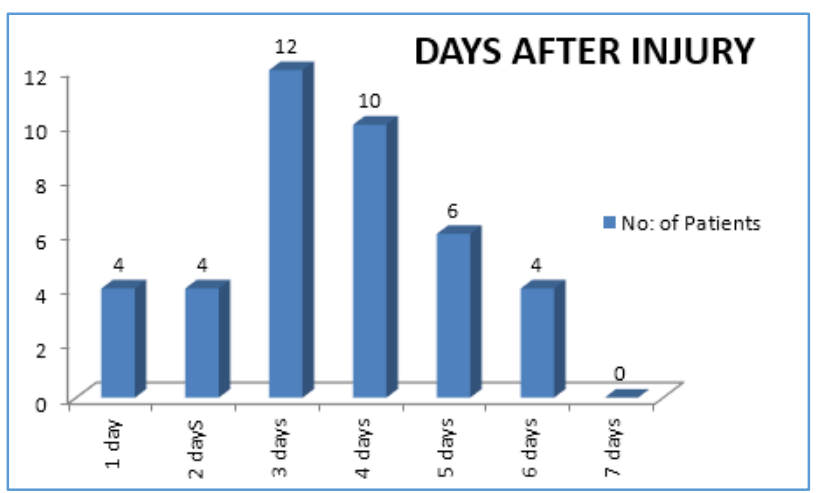

Figure 32. Timing of Surgery

\section{OPERATIVE TIME}

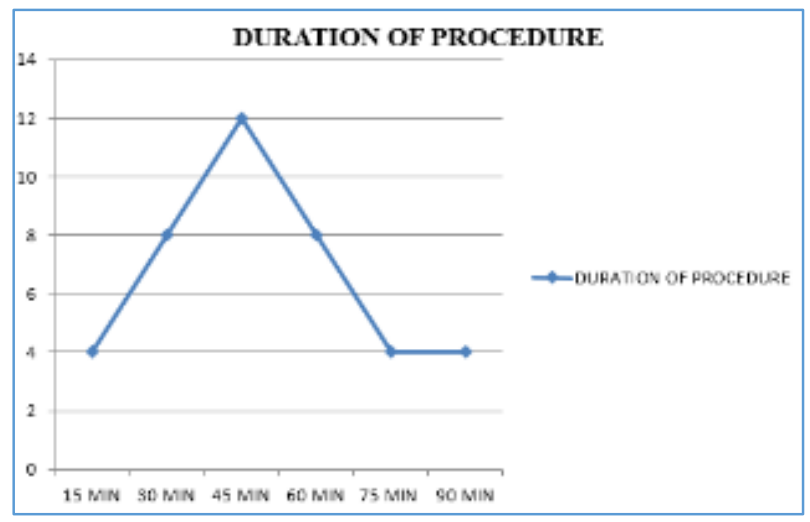

Figure 33. Duration of Procedure 
The mean surgical time for the procedure is 49.5 minutes, ranging from 15 to 90 minutes.

\begin{tabular}{|c|c|c|}
\hline Sl. No. & $\begin{array}{c}\text { Shoulder } \\
\text { movements }\end{array}$ & $\begin{array}{c}\text { Average (mean } \pm \text { standard } \\
\text { deviation) }\end{array}$ \\
\hline 1. & Flexion & $164.87 \pm 10.408$ \\
\hline 2. & Abduction & $165.13 \pm 10.284$ \\
\hline 3. & External rotation & $72.13 \pm 6.394$ \\
\hline 4. & Internal rotation & $73.88 \pm 5.716$ \\
\hline \multicolumn{3}{|c|}{ Table 1. Range of Movements } \\
\hline
\end{tabular}

\begin{tabular}{|c|c|c|}
\hline Fracture Type & $\begin{array}{c}\text { Average Time For } \\
\text { Union(WEEKS) }\end{array}$ & $\begin{array}{c}\text { Average Constant } \\
\text { Score (mean } \pm \\
\text { standard deviation) }\end{array}$ \\
\hline A0 15 B1 & 8.25 & $90.50 \pm 4.011$ \\
\hline A0 15 B2 & 9.63 & $88.75 \pm 3.715$ \\
\hline $\begin{array}{c}\text { Overall } \\
\text { (B1+B2) }\end{array}$ & 8.8 & $89.80 \pm 3.943$ \\
\hline \multicolumn{2}{|r}{ Table 2. Time Taken for Fracture Union }
\end{tabular}

\begin{tabular}{|c|c|c|c|c|}
\hline $\begin{array}{c}\text { Sl. } \\
\text { NO. }\end{array}$ & Result & $\begin{array}{c}\text { Constant } \\
\text { Score }\end{array}$ & $\begin{array}{c}\text { No. of } \\
\text { Patients }\end{array}$ & Percentage \\
\hline 1. & Excellent & $86-100$ & 36 & $90 \%$ \\
\hline 2. & Good & $71-85$ & 4 & $10 \%$ \\
\hline 3. & Fair & $56-70$ & 0 & $0 \%$ \\
\hline 4. & Poor & $1-55$ & 0 & $0 \%$ \\
\hline \multicolumn{5}{|r|}{ Table 3. Functional Evaluation Using Constant Score } \\
\hline
\end{tabular}

\begin{tabular}{|c|c|c|c|c|c|c|}
\hline & $\mathrm{n}$ & Mean & S.D. & $\mathrm{t}$ & Df & $\begin{array}{l}\text { Statistical } \\
\text { inference }\end{array}$ \\
\hline \multicolumn{7}{|l|}{ Age } \\
\hline B1 & 24 & 34.71 & 10.071 & \multirow[b]{2}{*}{-0.145} & \multirow[b]{2}{*}{38} & \multirow{2}{*}{$\begin{array}{c}0.886>0.05 \\
\text { Not } \\
\text { Significant }\end{array}$} \\
\hline B2 & 16 & 35.19 & 10.572 & & & \\
\hline \multicolumn{7}{|l|}{$\begin{array}{l}\text { Days before } \\
\text { surgery }\end{array}$} \\
\hline B1 & 24 & 3.42 & 1.412 & \multirow[b]{2}{*}{-0.726} & \multirow[b]{2}{*}{38} & \multirow{2}{*}{$\begin{array}{c}0.472>0.05 \\
\text { Not } \\
\text { Significant }\end{array}$} \\
\hline B2 & 16 & 3.75 & 1.438 & & & \\
\hline \multicolumn{7}{|l|}{ FU months } \\
\hline B1 & 24 & 8.58 & 2.104 & \multirow[b]{2}{*}{-0.835} & \multirow[b]{2}{*}{38} & \multirow{2}{*}{$\begin{array}{c}0.409>0.05 \\
\text { Not } \\
\text { Significant }\end{array}$} \\
\hline B2 & 16 & 9.13 & 1.857 & & & \\
\hline \multicolumn{7}{|l|}{ Union } \\
\hline B1 & 24 & 8.25 & 1.800 & \multirow{2}{*}{2.356} & \multirow{2}{*}{38} & $0.024<0.05$ \\
\hline B2 & 16 & 9.63 & 1.821 & & & Significant \\
\hline \multicolumn{7}{|l|}{ Flexion } \\
\hline B1 & 24 & 165.42 & 10.521 & \multirow{2}{*}{0.399} & \multirow[b]{2}{*}{38} & \multirow{2}{*}{$\begin{array}{c}0.692>0.05 \\
\text { Not } \\
\text { Significant } \\
\end{array}$} \\
\hline B2 & 16 & 164.06 & 10.523 & & & \\
\hline \multicolumn{7}{|l|}{ Abduction } \\
\hline B1 & 24 & 164.79 & 10.160 & \multirow[b]{2}{*}{-0.248} & \multirow[b]{2}{*}{38} & \multirow{2}{*}{$\begin{array}{c}0.805>0.05 \\
\text { Not } \\
\text { Significant }\end{array}$} \\
\hline B2 & 16 & 165.63 & 10.782 & & & \\
\hline \multicolumn{7}{|l|}{$\begin{array}{l}\text { External } \\
\text { Rotation }\end{array}$} \\
\hline B1 & 24 & 72.71 & 6.252 & \multirow[b]{2}{*}{0.702} & \multirow[b]{2}{*}{38} & \multirow{2}{*}{$\begin{array}{c}0.487>0.05 \\
\text { Not } \\
\text { Significant } \\
\end{array}$} \\
\hline B2 & 16 & 71.25 & 6.708 & & & \\
\hline \multicolumn{7}{|l|}{$\begin{array}{l}\text { Internal } \\
\text { Rotation }\end{array}$} \\
\hline B1 & 24 & 73.54 & 6.164 & \multirow{2}{*}{-0.447} & \multirow{2}{*}{38} & \multirow{2}{*}{$\begin{array}{c}0.657>0.05 \\
\text { Not } \\
\text { Significant }\end{array}$} \\
\hline B2 & 16 & 74.38 & 5.123 & & & \\
\hline $\begin{array}{c}\text { Constant } \\
\text { score }\end{array}$ & & & & & & \\
\hline
\end{tabular}

\begin{tabular}{|c|c|c|c|c|c|c|}
\hline B1 & 24 & 90.50 & 4.011 & \multirow[b]{2}{*}{1.391} & \multirow[b]{2}{*}{38} & \multirow{2}{*}{$\begin{array}{c}0.172>0.05 \\
\text { Not } \\
\text { Significant }\end{array}$} \\
\hline B2 & 16 & 88.75 & 3.715 & & & \\
\hline \multicolumn{7}{|c|}{ Result } \\
\hline B1 & 24 & 1.88 & 0.338 & \multirow[b]{2}{*}{-0.632} & \multirow[b]{2}{*}{38} & \multirow{2}{*}{$\begin{array}{c}0.531>0.05 \\
\text { Not } \\
\text { Significant } \\
\end{array}$} \\
\hline B2 & 16 & 1.94 & 0.250 & & & \\
\hline \multicolumn{7}{|c|}{ Table 4: T Test } \\
\hline
\end{tabular}

At the end of the study, we had all the 40 patients in the followup group with 28 male and 12 female patients. The mean age was 34.71 years (range 22-55 years) in the group.

The mean time interval between injury and surgery was 3.55 days (range 1-6 days). In the group, 24 patients had AO class B1 and 16 had AO class B2 fractures.

All the patients achieved clinical and radiological union at a mean of 8.8 weeks (Range 6-12 weeks). Eleven of the 24 patients had closed nailing while 16 patients (40\%) required open reduction of their fracture. The average size of the titanium flexible nail used was $2.5 \mathrm{~mm}$ (range $2-3 \mathrm{~mm}$ ).

The patients were followed up postoperatively and Constant scores were calculated at 6 weeks, 8 weeks, 10 weeks, 3 months and 6 months. The average constant score was 89.80 (range 78 - 95).

The nails were removed at an average of 6 months postoperatively, after the fracture had clinically and radiologically healed. One patient had medial protrusion of the nail with local skin perforation which was subsequently removed early after fracture has united at around 3 months.

There were no major complications in our series with only one case of local skin infection due to medial hardware prominence. No other complications like scar neuromas, nonunions or perforation of the posterior cortex were reported. And there were no cases of re-fracture after implant removal.

Comparing fracture type and union time $t$ test values obtained was 0.024 which is statistically significant. Comparing constant score with fracture type t test values obtained was 0.172 which is statistically not significant. No other factors are statistically significant.

\section{DISCUSSION}

\section{Surgical Technique}

The patient was placed in supine position on radiolucent table with a sandbag under ipsilateral shoulder. Care was taken to make sure that the sternoclavicular joint was accessible for the entry point.

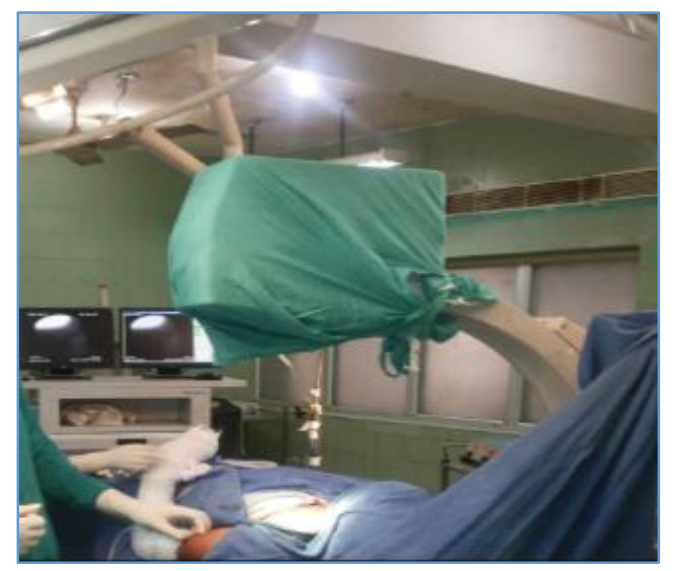

Figure 2. Patient Position after Draping with C-arm Perpendicular to the Table and Monitor at Foot end 
A one $\mathrm{cm}$ horizontal incision was made just lateral to the Sternoclavicular joint. The pectoral fascia was divided in line with the skin incision followed by careful elevation of the underlying musculature from the clavicle.

The entry point was then made using the awl directly or can be pre-drilled with a $2.7 \mathrm{~mm}$ drill bit to make a foot print.

Appropriate-sized titanium ESIN, after being loaded in $\mathrm{T}$ handle was inserted (The size of the nail was measured using this formula $=0.4 \times$ canal diameter in $\mathrm{mm}$ ).

If the fracture could not be reduced by closed means, then a separate mini open incision was used at the fracture site for direct manipulation of fragments.

The nail is then passed from the medial side and after reaching the end point, the nail is cut close as to prevent soft tissue irritation but leaving behind sufficient length for the extraction to be easy later on. The fascia and skin were closed in layers.

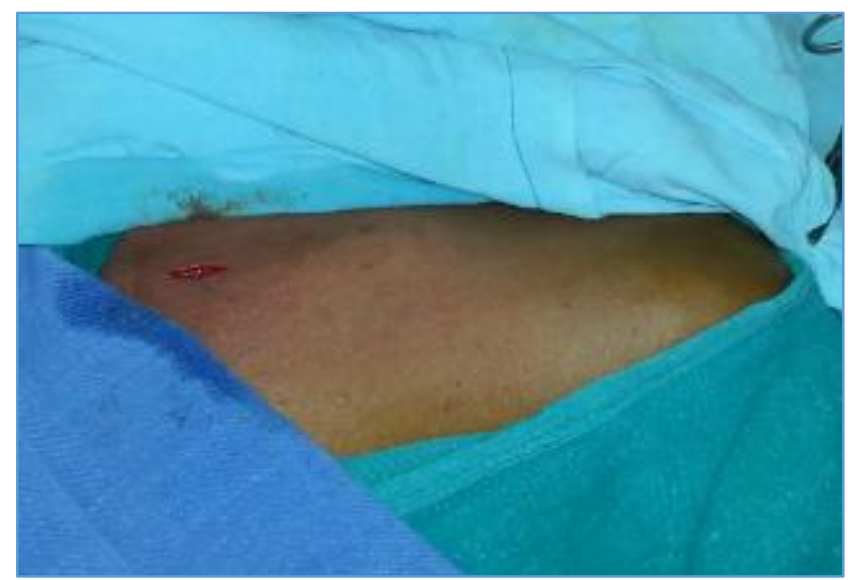

Figure 3. Skin Incision Lateral to SC Joint

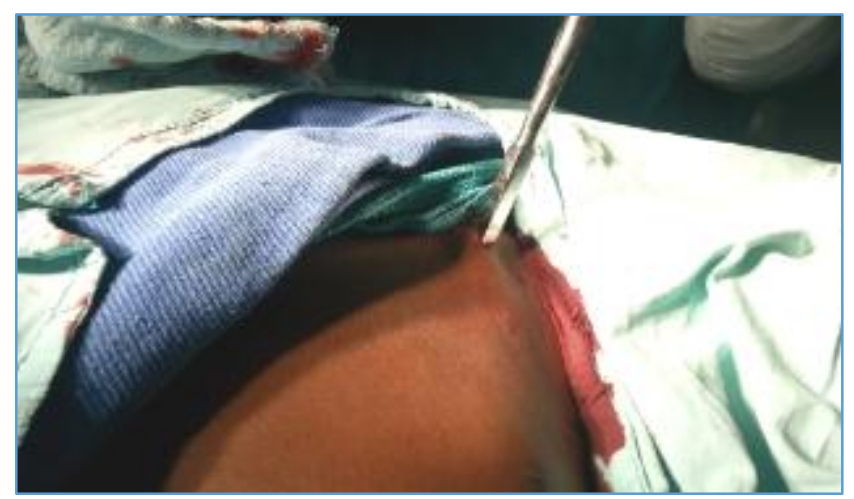

Figure 4. Entry with Bone Awl

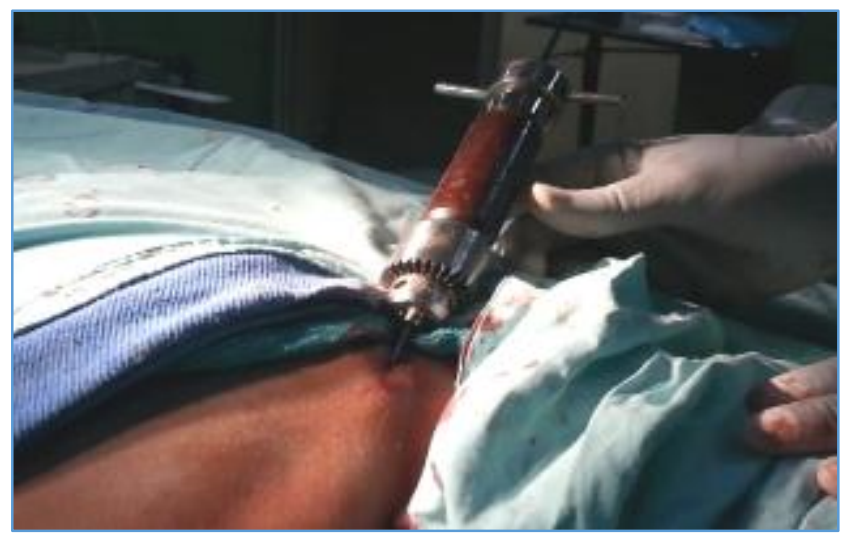

Figure 5. Insertion of TENS nail with a T-handle

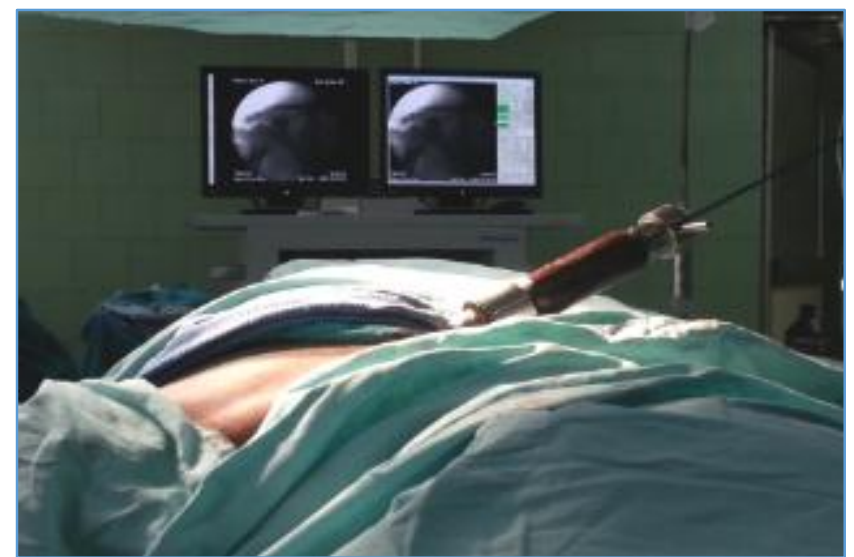

Figure 6. Manipulation under Fluoroscopic Control

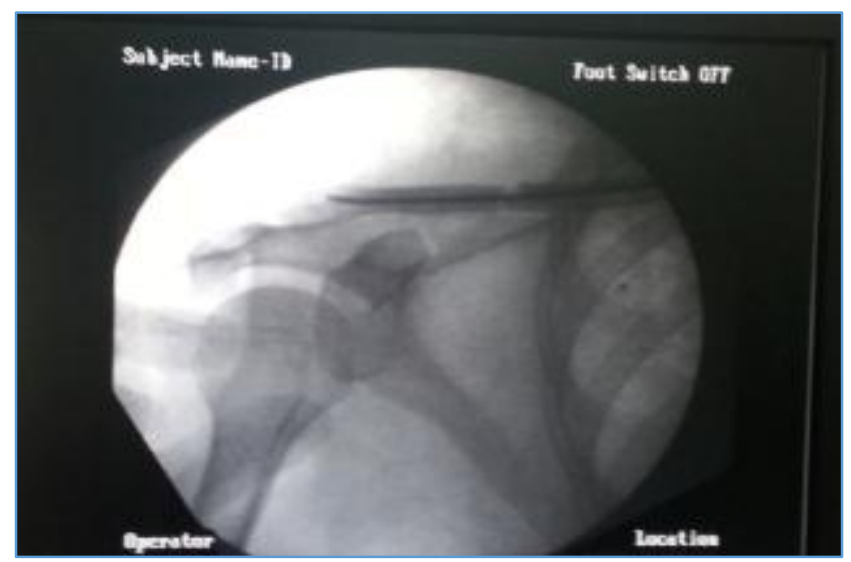

Figure 7. Intraoperative Fluoroscopic Image after Reduction

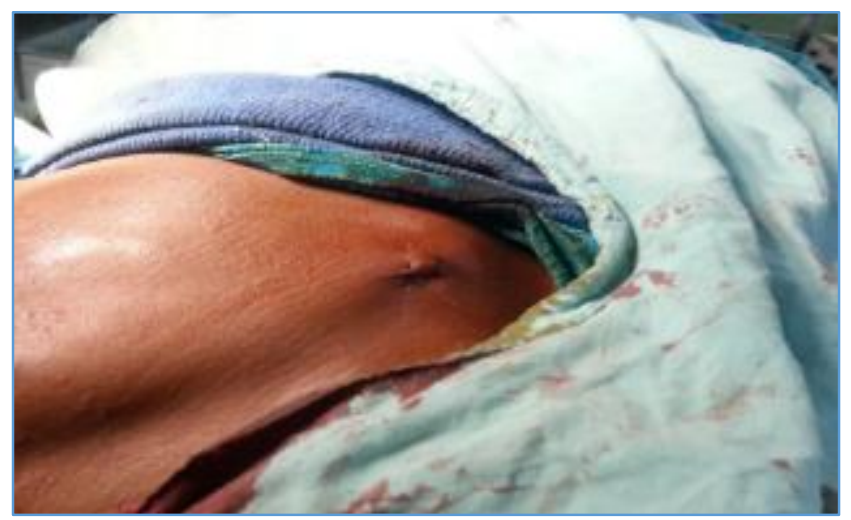

Figure 8. After Wound Closure

\section{Postoperative Protocol}

Pendular exercises for the shoulder were started from the second day. And all the patients were discharged on the second postoperative day.

After 7 days, active range of movement exercises were started, however, overhead shoulder abduction was allowed only after 2 weeks. Thereafter, activities of daily living were started, but those requiring lifting heavy objects were delayed until radiological and clinical union was achieved.

All patients were reviewed in the outpatient department at 2 and 6 weeks, 8 weeks, 10 weeks, 3 months, 6 months and 12 months after surgery.

The fracture shortening of $20 \mathrm{~mm}$ at initial stage showed high significant association with non-union; thus increasing 
the chance of an unsatisfactory result. Shortening of $20 \mathrm{~mm}$ or more finally following fixation was associated with an unsatisfactory result, but not with non-union. No other patient variable, fracture characteristic or treatment factor had a significant effect on final outcome. ${ }^{5}$

Surgery has been indicated for completely displaced fractures, potential skin perforation, shortening of clavicle by more than $20 \mathrm{~mm}$, neurovascular injury, and floating injury. ${ }^{9}$ The gold standard for the surgical treatment has been open reduction and plate fixation through a large incision. ${ }^{9}$

Plate osteosynthesis, ${ }^{10,11}$ external fixation ${ }^{12}$ and intramedullary fixation $13,14,15,16,17$ have all been described for surgical treatment of clavicle fractures. Plate osteosynthesis is still considered the standard method for the surgical treatment of clavicle fractures.

The advantage of plate fixation is good reduction with compression and rigid fixation.

However, complications after plate osteosynthesis are fairly common. In a multicentre prospective randomised trial, plate osteosynthesis had better functional outcome than nonoperative treatment of displaced clavicle fractures with decreased rate of non-union and symptomatic malunion. ${ }^{10}$

Severe complications occur in $10 \%$ of the patients and include deep infection, non-union, implant failure and fracture after implant removal. Lesser complications include superficial infection, keloid scar, dysesthaesia in the region of scar, as well as implant loosening with loss of reduction. ${ }^{18}$

Intramedullary stabilisation is an established alternative fixation method.

Intramedullary implants are ideal from the biomechanical point of view as the tension side of clavicle changes with respect to rotation of arm and direction of loading.8,14.

The other potential benefits of intramedullary nailing include smaller incision, minimal periosteal stripping and load sharing device properties. ${ }^{19}$ Its relative stability allows copious callus formation during the healing process.

The frequent complication encountered is skin irritation from the prominent medial end of the nail and this frequently leads to premature removal of the nail. ${ }^{18}$

Usage of TENS nail in multifragmentary fracture can lead to telescoping of the nail with shortening of the clavicle. Thus, the comminuted fractures were excluded as the nail cannot maintain length of the clavicle in these situations. Smekal et al hence do not recommend use of intramedullary nail in comminuted fractures with severe shortening. 18

Duan et al in a meta-analysis of randomised controlled trials demonstrated similar functional outcome when comparing plating with intramedullary fixation. ${ }^{20}$ They, however, showed higher symptomatic hardware-related problems with plating.

Zolowodzki et al in a systematic review of 2144 cases found non-union rate of $1.6 \%$ with intramedullary fixation as compared with $2.5 \%$ with plate fixation. ${ }^{20}$

Achieving closed reduction was a difficult task especially in AO B2 fractures and in obese individuals. If reduction could not be achieved closed; a mini open incision can be made to reduce the fracture. So that the surgical time as well as the radiation exposure for both the patient and surgeon can be reduced.

Despite all these, we achieved good functional and cosmetic outcome in diaphyseal midshaft, non-comminuted clavicle fractures with more than $20 \mathrm{~mm}$ shortening/displacement with intramedullary titanium elastic nail system with no major complications.

In our study, there is significant statistical correlation between fracture type and time for union $(\mathrm{p}<.024)$ although no other variable showed statistical significance.

\section{CONCLUSION}

Thus, the intramedullary fixation of displaced midshaft clavicle fracture is a safe and minimally invasive technique.

From this study, we recommend the use of minimally invasive antegrade titanium elastic nail for fixation of displaced midshaft clavicle fractures in view of:

- Faster fracture union.

- Quicker rehabilitation.

- Lesser morbidity.

- Easier implant removal and

- Fewer complications.

\section{REFERENCES}

[1] Craig EV. Fractures of the clavicle. In: Rockwood CA, Matsen FA. eds. The shoulder. 3rd edn. Philadelphia, PA: WB Saunders 1998:428-82.

[2] Neer CS. Nonunion of the clavicle. J Am Med Assoc 1960;172(10):1006-11.

[3] Neviaser JS. The treatment of fractures of the clavicle. Surg Clin North Am 1963;43:1555-63.

[4] Rowe CR. An atlas of anatomy and treatment of midclavicular fractures. Clin Orthop Relat Res 1968;58:29-42.

[5] Hill JM, McGuire MH, Crosby LA. Closed treatment of displaced middle-third fractures of the clavicle gives poor results. J Bone Joint Surg Br 1997;79(4):537-9.

[6] McKee MD, Pedersen EM, Jones C, et al. Deficits following nonoperative treatment of displaced midshaft clavicular fractures. J Bone Joint Surg Am 2006;88(1):35-40.

[7] Zlowodzki M, Zelle BA, Cole PA, et al. Treatment of acute midshaft clavicle fractures: systematic review of 2,144 fractures: on behalf of the Evidence-Based Orthopaedic Trauma Working Group. J Orthop Trauma 2005;19(7):504-7.

[8] Smekal V, Irenberger A, Struve P, et al. Elastic stable intramedullary nailing versus nonoperative treatment of displaced midshaft clavicular fractures - a randomized, controlled, clinical trial. J Orthop Trauma 2009;23(2):106-12.

[9] Frigg A, Rillmann P, Perren T, et al. Intramedullary nailing of clavicular midshaft fractures with the titanium elastic nail: problems and complications. Am J Sports Med 2009;37(2):352-9.

[10] Canadian Orthopaedic Trauma Society. Nonoperative treatment compared with plate fixation of displaced midshaft clavicular fractures. A multicenter, randomized clinical trial. J Bone Joint Surg Am 2007;89(1):1-10.

[11] Mullaji AB, Jupiter JB. Low-contact dynamic compression plating of the clavicle. Injury 1994;25(1):41-5.

[12] Schuind F, Pay-Pay E, Andrianne Y, et al. External fixation of the clavicle for fracture or non-union in adults. J Bone Joint Surg Am 1988;70(5):692-5. 
[13] Khalil A. Intramedullary screw fixation for midshaft fractures of the clavicle. Int Orthop 2009;33(5):14214.

[14] Mueller M, Rangger C, Striepens N, et al. Minimally invasive intramedullary nailing of midshaft clavicular fractures using titanium elastic nails. J Trauma 2008;64(6):1528-34.

[15] Ferran NA, Hodgson P, Vannet N, et al. Locked intramedullary fixation vs plating for displaced and shortened mid-shaft clavicle fractures: a randomized clinical trial. J Shoulder Elbow Surg 2010;19(6):783-9.

[16] Kleweno CP, Jawa A, Wells JH, et al. Midshaft clavicular fractures: comparison of intramedullary pin and plate fixation. J Shoulder Elbow Surg 2011;20(7):1114-7.
[17] Liu HH, Chang CH, Chia WT, et al. Comparison of plates versus intramedullary nails for fixation of displaced midshaft clavicular fractures. J Trauma 2010;69(6):E82-7.

[18] Smekal V, Irenberger A, Attal RE, et al. Elastic stable intramedullary nailing is best for mid-shaft clavicular fractures without comminution: results in 60 patients. Injury 2011;42(4):324-9.

[19] Millett PJ, Hurst JM, Horan MP, et al. Complications of clavicle fractures treated with intramedullary fixation. J Shoulder Elbow Surg 2011;20(1):86-91.

[20] Duan X, Zhong G, Cen S, et al. Plating versus intramedullary pin or conservative treatment for midshaft fracture of clavicle: a meta-analysis of randomized controlled trials. J Shoulder Elbow Surg 2011;20(6):1008-15. 